\title{
PENGARUH PANJANG TALI, MASSA DAN DIAMETER BANDUL TERHADAP PERIODE DENGAN VARIASI SUDUT
}

\author{
Yuli Yanti $^{1}$, Neng Nenden Mulyaningsih ${ }^{2}$, Dandan Luhur Saraswati ${ }^{3}$ \\ Pendidikan Fisika, Universitas Indraprasta PGRI \\ yuli.yantibisa@gmail.com, nenk_nen@yahoo.com, dandanluhur09@gmail.com
}

Submitted February 17, 2020; Revised June 12, 2020; Accepted July 2, 2020

\begin{abstract}
Abstrak
Dalam praktikum fisika dasar terdapat beberapa penyederhanaan kasus yang bertujuan untuk mendukung pemahaman konsep pembelajaran fisika. Pada pelaksanaan praktikum terdapat proses pembuktian yang dilakukan melalui sebuah percobaan dan melibatkan suatu perumusan. Hal ini dapat ditemui pada percobaan bandul sederhana, di dalamnya terdapat penyederhaan kasus yang mempermudah pemahaman terhadap faktor yang mempengaruhi nilai periode bandul. Oleh karena itu, penelitian ini bertujuan untuk membuktikan nilai periode bandul berdasarkan data hasil eksperimen dan data hasil perhitungan berdasarkan rumus. Metode eksperimen yang dilakukan yaitu dengan menggunakan alat peraga bandul sederhana dan mengamati pengaruh massa bandul, diameter bandul, panjang tali, dan simpangan sudut terhadap nilai periode bandul. Variasi sudut yang dipilih yaitu $15^{\circ}$, $30^{\circ}$ dan $45^{\circ}$. Hasil yang diperoleh menunjukkan bahwa pada sudut $15^{\circ}$, besarnya periode hanya bergantung pada nilai perubahan panjang tali, sedangkan pada sudut $30^{\circ}$ dan $45^{\circ}$, besarnya sudut mempengaruhi nilai periode. Massa bandul dan diameter bandul tidak mempengaruhi besarnya periode untuk semua variasi sudut. Nilai periode yang diperoleh berdasarkan hasil eksperimen dan perhitungan rumus tidak menunjukkan nilai yang berbeda signifikan.
\end{abstract}

Kata Kunci : Periode bandul, massa bandul, diameter bandul, panjang tali, simpangan sudut

\begin{abstract}
In basic physics practicums there are some simplification of cases that aim to support the understanding of physics learning concepts. In practicum implementation there is a proof process that is carried out through an experiment and involves a formulation. This can be found in simple pendulum experiments, in which there are simplified cases that facilitate understanding of the factors that affect the pendulum period value. Therefore, this study aims to prove the value of the pendulum period based on experimental results and calculation data based on formulas. The experimental method used is to use simple pendulum props and observe the effect of pendulum mass, pendulum diameter, length of the rope, and angle deviation on the value of the pendulum period. The angle variations chosen were $15^{\circ}, 30^{\circ}$ and $45^{\circ}$. The results obtained show that at an angle of $15^{\circ}$, the magnitude of the period depends only on the value of the change in the length of the rope, while at an angle of $30^{\circ}$ and $45^{\circ}$, the magnitude of the angle affects the value of the period. The pendulum mass and pendulum diameter do not affect the magnitude of the period for all angular variations. Period values obtained based on experimental results and formula calculations do not show significantly different values.
\end{abstract}

Key Words : Pendulum period, pendulum mass, pendulum diameter, length of rope, angle deviation

\section{PENDAHULUAN}

Gerakan ayunan secara bolak balik, gerak maju mundur piston-piston pada mesin mobil, dan gerak ayunan pendulum pada jam kuno merupakan contoh gerak periodik, dimana gerakan tersebut bergerak secara berulang dan kembali diam pada posisi kesetimbangannya yang stabil [1]. Gerak periodik juga disebut osilasi, benda akan berosilasi jika diberikan gaya atau torsi untuk menjauhi titik setimbangnya, 
ketika berosilasi benda tersebut akan bergerak bolak balik melewati titik kesetimbangannya dan gaya pemulih yang bekerja akan cenderung mengembalikan sistem pada keadaan kesetimbangannya [2].

Gerak harmonik sederhana (GHS) merupakan salah satu contoh gerak periodik apabila osilasi dalam sistemnya mempunyai amplitudo yang cukup kecil yaitu dengan simpangan kurang dari $15^{\circ}$. Eksperimen atau percobaan yang dapat dilakukan dalam mengapliksikan gerak harmonik sederhana salah satunya yaitu pembuatan bandul matematis atau pendulum sederhana [3]. Pendulum sederhana (simple pendulum) merupakan model yang disempurnakan yang terdiri dari sebuah massa titik yang ditahan oleh benang kaku tak bermasa (massa diabaikan) [4]. Apabila bandul dilepaskan diberi simpangan dari posisi setimbangnya maka bandul tersebut akan berosilasi bergerak secara bolak balik melewati posisi setimbangnya [5], [6], [7]. Selama berosilasi, sebuah bandul akan mempunyai periode, frekuensi, dan frekuensi sudut. Periode menyatakan banyaknya waktu yang dibutuhkan untuk melakukan satu kali getaran penuh, frekuensi menyatakan banyaknya getaran yang terjadi tiap satuan detik, dan frekuensi sudut menyatakan besarnya kecepatan rotasi [8], [9].

Dalam rumus periode bandul $\mathrm{T}=2 \pi \sqrt{\frac{L}{g}}$ terdapat tiga hal yang mempengaruhi besarnya periode yaitu besarnya nilai $2 \pi$ yang konstan, panjang tali dan percepatan gravitasi [10]. Pada penelitian ini bertujuan untuk membuktikan rumus tersebut dengan melakukan ekperimen alat peraga bandul sederhana dan mengamati pengaruh massa bandul, diameter bandul, panjang tali, dan simpangan sudut terhadap nilai periode bandul.

Telah banyak penelitian sebelumnya yang membahas mengenai pembuktian rumus periode bandul, seperti yang telah dilakukan oleh K. Khotimah, S. Viridi, \& N. Khotimah (2011); dan H. Widya (2019). Namun masih jarang yang melakukan analisis terhadap variasi massa bandul dan besarnya sudut.

Dengan adanya eksperimen alat peraga ini diharapkan dapat meningkatkan keterampilan proses dan pemahaman konsep mengenai gerak harmonik sederhana dapat semakin dikuasai.

\section{METODE PENELITIAN}

Jenis penelitian ini adalah penelitian eksperimen. Percobaan bandul sederhana ini dilakukan dengan pengambilan data secara berulang untuk mendapatkan nilai rata-rata dan standar deviasi dari hasil yang didapat, secara umum pengukuran osilasi bandul ini dilakukan dengan memvariasikan massa, diameter, panjang tali, dan sudut simpangan awal.

Dalam proses pengambilan data, digunakan beberapa jenis peralatan. Peralatan yang digunakan terdiri dari satu set penggantung statif, neraca ohauss 4 lengan, mikrometer sekrup, jangka sorong, busur derajat, tali, stopwatch, mistar, bola bekel 3 buah dengan ukuran yang berbeda (besar, sedang, dan kecil), bola pingpong, dan kelereng.

Semua pengumpulan data dilakukan dengan pengukuran berulang sebanyak 5 kali, dimulai dari pengukuran massa beban dengan neraca ohauss 4 lengan, pengukuran diameter beban dengan mikrometer sekrup dan jangka sorong, mengukur panjang tali menggunakan mistar, mengaitkan beban pada tali, menggantungkan tali dan beban pada statif, mengatur derajat simpangan sudut dengan busur derajat, dan mengayunkan beban serta mencatat waktu yang diperlukan untuk beban tersebut berosilasi sebanyak 10 kali. 
Data yang didapat berupa massa bandul, diameter bandul, panjang tali, dan waktu yang diperlukan untuk 10 kali berosilasi, lalu data tersebut diolah untuk mendapatkan nilai rata-rata, standar deviasi, dan periode ekperimen dengan perumusan $\mathrm{T}_{\text {eksperimen }}=\frac{\bar{t}}{n}$, kemudian membandingkannya dengan nilai periode bandul meggunakan persamaan $\mathrm{T}_{\text {teori }}=2 \pi \sqrt{\frac{L}{g}}$ serta mengamati pengaruh massa, diameter, panjang tali, dan sudut simpangan awal terhadap besarnya periode bandul.

\section{HASIL DAN PEMBAHASAN}

Penelitian ini menggunakan empat parameter percobaan, di antaranya mengamati pengaruh panjang tali terhadap nilai rata-rata periode bandul, pengaruh simpangan sudut awal terhadap nilai ratarata periode bandul, pengaruh massa beban terhadap nilai rata-rata periode bandul, dan pengaruh diameter beban terhadap nilai rata-rata periode bandul. Berdasarkan proses pengambilan data dan pengolahan data yang mengacu pada penurunan perumusan teori periode bandul, maka analisis data didapatkan seperti tabel berikut:

Tabel 1. Pengaruh Panjang Tali Terhadap Nilai Rata-rata Periode Bandul

\begin{tabular}{lccccc}
\hline Jenis Massa & Panjang tali $(\boldsymbol{c m})$ & Osilasi $(\boldsymbol{n})$ & $\overline{\boldsymbol{t}}(\boldsymbol{s})$ & $\boldsymbol{T}_{\text {eksperimen }}(\boldsymbol{s})$ & $\boldsymbol{T}_{\text {teori }}(\boldsymbol{s})$ \\
\hline \multirow{3}{*}{ Bola bekel kecil } & 30 & 10 & 11,11 & 1,11 & 1,09 \\
& 40 & 10 & 12,84 & 1,28 & 1,26 \\
& 50 & 10 & 14,03 & 1,40 & 1,40 \\
\hline
\end{tabular}

Tabel 2. Pengaruh Simpangan Sudut Awal Terhadap Nilai Rata-rata Periode Bandul

\begin{tabular}{lccccc}
\hline Jenis Massa & Sudut $\left(^{\circ}\right)$ & Osilasi $(\boldsymbol{n})$ & $\overline{\boldsymbol{t}}(\boldsymbol{s})$ & $\boldsymbol{T}_{\text {eksperimen }}(\boldsymbol{s})$ & $\boldsymbol{T}_{\text {teori }}(\boldsymbol{s})$ \\
\hline \multirow{3}{*}{ Bola bekel sedang } & 15 & 10 & 14,16 & 1,42 & 1,40 \\
& 30 & 10 & 14,56 & 1,46 & 1,43 \\
& 45 & 10 & 14,71 & 1,47 & 1,46 \\
\hline
\end{tabular}

Tabel 3. Pengaruh Massa Beban Terhadap Nilai Rata-rata Periode Bandul

\begin{tabular}{lccccc}
\hline Jenis Massa & Massa $(\boldsymbol{g})$ & Osilasi $(\boldsymbol{n})$ & $\overline{\boldsymbol{t}}(\boldsymbol{s})$ & $\boldsymbol{T}_{\text {eksperimen }}(\boldsymbol{s})$ & $\boldsymbol{T}_{\text {teori }}(\boldsymbol{s})$ \\
\hline Bola bekel kecil & 15,39 & 10 & 14,03 & 1,40 & 1,40 \\
Kelereng & 2,7 & 10 & 14,16 & 1,42 & 1,40 \\
Bola Pingpong & 5,25 & 10 & 14,33 & 1,43 & 1,40 \\
\hline
\end{tabular}

Tabel 4. Pengaruh Diameter Beban Terhadap Nilai Rata-rata Periode Bandul

\begin{tabular}{lccccc}
\hline Jenis Massa & Diameter $(\boldsymbol{c m})$ & Osilasi $(\boldsymbol{n})$ & $\overline{\boldsymbol{t}}(\boldsymbol{s})$ & $\boldsymbol{T}_{\text {eksperimen }}(\boldsymbol{s})$ & $\boldsymbol{T}_{\text {teori }}(\boldsymbol{s})$ \\
\hline Bola bekel besar & 4,52 & 10 & 14,26 & 1,43 & 1,40 \\
Bola bekel sedang & 4,01 & 10 & 14,16 & 1,42 & 1,40 \\
Bola bekel kecil & 3,13 & 10 & 14,03 & 1,40 & 1,40 \\
\hline
\end{tabular}


Tabel 1 menunjukkan pengaruh panjang tali terhadap besar nilai rata-rata periode dengan menggunakan bola bekel kecil sebagai bandul yang memiliki massa 15,39 gram, diameter $3,13 \mathrm{~cm}$, sudut tetap $15^{\circ}$, dan variasi ukuran panjang tali $30 \mathrm{~cm}, 40$ $\mathrm{cm}, 50 \mathrm{~cm}$. Penelitian dilakukan dengan mengayunkan bandul sampai bandul tersebut berosilasi sebanyak 10 kali. Dari data tabel 1 didapat hubungan bahwa panjang tali mempengaruhi pertambahan periode ayunan karena bersarnya periode berbanding lurus dengan panjang tali, hal tersebut sesuai dengan teori perumusan periode bandul:

$$
T=2 \pi \sqrt{\frac{L}{g}}
$$

Tabel 2 menunjukkan pengaruh besar sudut simpangan awal terhadap besar nilai rata-rata periode, dengan menggunakan bola bekel sedang sebagai bandul yang memiliki massa 31,9 gram, diameter 4,01 $\mathrm{cm}$, panjang tali tetap $50 \mathrm{~cm}$, dan variasi sudut $15^{\circ}, 30^{\circ}, 45^{\circ}$. Percobaan dilakukan dengan mengayunkan bandul sampai bandul tersebut berosilasi sebanyak 10 kali. Dari data tabel 2 didapat hubungan bahwa simpangan sudut awal mempengaruhi pertambahan periode ayunan apabila sudut yang disimpangkan tidak relatif kecil. Besarnya nilai periode rata-rata ayunan $\langle T\rangle$ bertambah dengan semakin besarnya nilai sudut simpangan awal. Demikian pula gaya berbanding lurus dengan simpangan hanya untuk simpangan kecil. Jika kita ingin menghitung periode untuk sembarang derajat kepresisian dan perpindahan sudut maksimumnya adalah $\Theta$ maka periode dapat dinyatakan dengan deret tak hingga, sesuai dengan teori persamaan :

$$
\begin{aligned}
T_{\Theta}=2 \pi \sqrt{\frac{L}{g}}\left[1+\frac{1}{2^{2}} \sin ^{2} \frac{1}{2} \Theta_{0}+\right. \\
\frac{1}{2^{2}}\left(\frac{3}{4}\right)^{2} \sin ^{4} \frac{1}{2} \Theta_{0}+ \\
\left.\frac{1}{2^{2}}\left(\frac{5}{8}\right)^{2} \sin ^{6} \frac{1}{2} \Theta_{0}+\cdots\right]
\end{aligned}
$$

Dari data pada Tabel 3 dengan panjang tali tetap $50 \mathrm{~cm}$, sudut tetap $15^{\circ}$, dan variasi massa yang berbeda didapatkan hasil dari $T_{\text {eksperimen }}=\frac{\bar{t}}{n}$ dan $T_{\text {teori }}$ nilai periode yang tidak jauh berbeda atau perbedaannya sangat tipis, maka dapat disimpulkan bahwa massa tidak mempengaruhi periode bandul, karena dalam osilasi bandul terdapat gaya pemulih yang besarnya $\mathrm{mg}$ $\sin \theta$, di dalam gaya tersebut terdapat variabel massa, dimana dalam suatu keadaan massa akan mempercepat dan memperlambat gerakan ayunan sehingga dapat memperbesar dan memperkecil periode, dengan begitu maka pengaruh totalnya sama dengan nol atau tidak berpengaruh.

Dari data pada Tabel 4 dengan panjang tali tetap $50 \mathrm{~cm}$, sudut simpangan awal tetap $15^{\circ}$, dan variasi jenis diameter yang berbeda, didapatkan hasil bahwa variasi diameter bandul dari benda sejenis tidak mempengaruhi besarnya periode bandul, sama seperti massa bandul yang tidak mempengaruhi periode ayunan.

\section{SIMPULAN}

Dari penelitian ini dapat disimpulkan bahwa nilai periode bandul dipengaruhi oleh beberapa faktor, di antaranya panjang tali yang digunakan dan sudut simpangan awal, sedangkan faktor yang tidak mempengaruhi periode adalah massa dan diameter bandul. Panjang tali mempengaruhi periode karena hubungan panjang tali dengan periode bandul berbanding lurus, semakin panjang tali maka periode bandul akan semakin besar, dan semakin pendek tali yang digunakan maka nilai periode akan semakil kecil. Sudut simpangan awal mempengaruhi besar nilai periode apabila sudut tersebut tidak relatif kecil, karena hanya sudut simpangan yang relatif kecillah yang tergolong ke dalam getaran harmonik sederhana, apabila sudut simpangan relatif 
besar maka perumusan periode memakai persamaan deret tak hingga untuk sembarang derajat kepresisian.

Saran dalam penelitian ini sebaiknya penelitian dilakukan dengan memproyeksikan sudut lebih detail dan dalam proses pengambilan data waktu osilasi diharapkan pengamat dapat lebih peka dalam penggunaan stopwatch.

\section{UCAPAN TERIMAKASIH}

Kami mengucapkan terima kasih kepada Universitas Indraprasta PGRI Jakarta melalui LPPM Universitas Indraprasta PGRI atas dana hibah penelitian DIPA Unindra sesuai kontrak penelitian Surat Perjanjian Pelaksanaan Tugas Penelitian Semester Ganjil Tahun Akademik 2019/2020 Nomor:

01455/SP3/KP/LPPM/UNINDRA/X/2019.

\section{DAFTAR PUSTAKA}

[1] I. Noor and A. Dewi, "Pengembangan Alat Peraga Bandul Matematis untuk Melatihkan Keterampilan Proses Siswa pada Materi Gerak Harmonik Sederhana di Kelas XI SMAN 3 Tuban," vol. 03, no. 02, pp. 189-194, 2014.

[2] E. Novianarenti, Y. Susatio, and R. Hantoro, "Penentuan Parameter Bandul Matematis untuk Memperoleh Energi Maksimum dengan Gelombang dalam Tangki," vol. 2, no. 1, 2013.

[3] H. Widya "Variasi Bentuk Bandul untuk Meningkatkan Pemahaman Peserta Didik Dalam Penentuan Nilai Gravitasi Bumi pada Ayunan Sederhana," vol. 3, no. 1, pp. 42-46, 2019.
[4] A. H. Setyadin et al., "Optimalisasi Bandul Matematis Menggunakan Tracker dalam Penentuan Perubahan Percepatan Gravitasi Permukaan Bumi (g) Akibat Gerhana Matahari Sebagian (GMS) 9 M," vol v. February, 2016.

[5] A. Bel, M. Brígido, and M. A. D, "Heliyon Improving the selfregulation in prospective science teachers : the case of the calculus of the period of a simple pendulum," vol. 5, November, 2019.

[6] S. Das and P. Wahi, "Initiation and Directional Control of Period-1 Rotation for Vertically or Horizontally Excited Parametric Pendulum," Procedia IUTAM, vol. 22, pp. 99-106, 2017.

[7] H. Chen, J. Li, and Z. He, "The existence of subharmonic solutions with prescribed minimal period for forced pendulum equations with impulses q," Appl. Math. Model., vol. 37, no. 6, pp. 4189-4198, 2013.

[8] K. Khotimah, S. Viridi, and N. Khotimah, "Ayunan Sederhana : Pengaruh Panjang Tali, Sudut Awal , dan Massa Bandul terhadap Periode serta Menentukan Konstanta Redaman," vol. 2011, no. SNIPS, pp. 22-23, 2011.

[9] C. Gauld, "The Treatment of Cycloidal Pendulum Motion in Newton's Principia," pp. 115-125, 2005.

[10] R. A. Nelson and M. G. Olsson, "The pendulum - Rich physics from a simple system," vol. 112, no. May 2013, 1986. 